Економічні науки: збірник наукових праиь Луиького національного технічного університету. - Серія "Регіональна економіка". - Випуск 16 (63). - Редкол.: відп. ред. д.е.н., професор Л.Л. Ковальська - Луцьк : ІВВ Луцького НТУ, 2019. -173 с.

УДК 332.1:658.512

Полінкевич О.М., д.е.н., проф.

Східноєвропейський національний університет імені Лесі Українки

\title{
РЕГІОНАЛЬНІ СИСТЕМИ РОЗВИТКУ БІЗНЕСУ ЧЕРЕЗ УПРАВЛІННЯ ФІЗИЧНОЮ АКТИВНІСТЮ СТЕЙКХОЛДЕРІВ
}

В статті зазначено, що рушійною силою економіки розвинених країн $\epsilon$ формування регіональних систем розвитку бізнесу, які не тільки рекомендуються, але й необхідні для забезпечення соціально-екологічного та економічного розвитку регіону, забезпечення його безпеку. Зазначено, що оскільки стейкхолдерів розглядають як фізичних, так і юридичних осіб, то підходів до підвищення фізичної активності $€$ два: заходи із впливу на фізичних осіб та заходи із залучення організація та установ до фізичної активності через розробку комплексу програм для їх працівників. Визначено сутність регіональної системи розвитку бізнесу, описано принципи іiі функціонування та умови реалізації.

Ключові слова: регіональна система розвитку бізнесу, управління, фізична активність, продуктивність праці, стейкхолдери.

\section{Polinkevych O.}

\section{REGIONAL BUSINESS DEVELOPMENT SYSTEMS THROUGH STAKEHOLDERS 'PHYSICAL ACTIVITY MANAGEMENT}

The article states that the driving force of the economies of developed countries is the formation of regional business development systems, which are not only recommended but also necessary to ensure the socio-ecological and economic development of the region, to ensure its security. It is noted that as stakeholders consider both physical and legal entities, there are two approaches to increasing 

університету. - Серія "Регіональна економіка". - Випуск 16 (63). - Редкол.: відп. ред. д.е.н., професор Л.Л. Ковальська - Луцьк : ІВВ Луцького НТУ, 2019. -173 с.

physical activity: 1) measures to influence individuals through their involvement in sports competitions, creating different kinds of draws with a win - visiting institutions engaged in physical activity of the population of the region at lower prices, creating promotional videos about healthy lifestyles; 2) measures to involve organizations and institutions in physical activity through the development of a range of programs for their employees, the promotion of healthy lifestyles, the development of systems to overcome fatigue at work, increase productivity at enterprises, the creation of trainings, symposia and conferences that promote physical activity as a tool to reduce the burden on the region's economy. The essence of the regional business development system is determined, the principles of its functioning and conditions of realization are described.

Regional business development system is a set of industrial, financial, commercial, social, environmental, sports and recreational activities in the region, which increase the competitive position of the region among other regions of Ukraine, affect the productivity and health of the population, increase the level of job satisfaction, personal and social life. Establishment of a regional system of business development based on the principles of transparency, openness, efficiency, environmental friendliness and mutual support for promoting the well-being and laying the foundations for sustainable socio-ecological and economic development of the territories. As everyone involved in the regional business development system is a stakeholder, more attention should be given to measures to manage their physical activity in order to achieve the socio-ecological and economic sustainable development of the region. Stakeholders' contribution to the regional business development system is power and incentives. Power can be technology, innovation, time, professional skills, knowledge, qualifications, soft and solid competencies. The incentives will be access to modern management technologies, the ability to conduct experiments through openness of society, advanced training, rewards in improving the level of satisfaction with work, personal and social life in the region, safe working conditions, a complete regional material and technological base, accessibility to energy-saving technologies, eco-friendly technologies status, exchange of experience with developed regions and territories. The main advantages of managing stakeholder in regional business systems are: the regional development priorities must be clear and have a common vision among its key influencers; identifying who are the main stakeholders and understanding their attitude to these systems; bringing people together, including their knowledge and experience, to solve problems together; defining the region's strategy for competitive advantage; reducing the level of risk in the region and increasing the level of security.

Effective engagement helps to transform stakeholder needs into organizational goals and provides the basis for developing an effective strategy. Finding a point of consensus or overall motivation helps the stakeholder group turn the investment into a meaningful outcome. For a regional business system to be successful, all parties must have a clear understanding of the process and goals. The information should be conveyed purposefully and consistently at each stage. Stakeholders need to understand the vision and role they play individually in 
Економічні науки: збірник наукових праџь Луцького національного технічного університету. - Серія "Регіональна економіка". - Випуск 16 (63). - Редкол.: відп. ред. д.е.н., професор Л.Л. Ковальська - Луцьк : ІВВ Луцького НТУ, 2019. -173 с.

achieving the goals of the region. Each stakeholder has to understand their own meaning and the role they play in achieving a common goal. Many of the activities suggested by increasing the physical activity of stakeholders cannot be implemented due to low awareness and lack of interaction between them. Engaging with stakeholders from the outset helps to engage them in the regional business system and assure their successful completion. Stakeholders who do not understand community development strategies find it difficult to stay engaged and move in the right direction.

Key words: regional business development system, management, physical activity, labor productivity, stakeholders.

\section{Полинкевич О.Н.}

\section{РЕГИОНАЛЬНЫЕ СИСТЕМЫ РАЗВИТИЯ БИЗНЕСА ПРИ УПРАВЛЕНИИ ФИЗИЧЕСКОЙ АКТИВНОСТЬЮ СТЕЙКХОЛДЕРОВ}

В статье указано, что движущей силой экономики развитых стран является формирование региональных систем развития бизнеса, не только рекомендуются, но и необходимые для обеспечения социально-экологического и экономического развития региона, обеспечения его безопасности. Указано, что поскольку стейкхолдеров рассматривают как физических, так и юридических лиц, то подходов к повышению физической активности два: меры по воздействию на физических лиц и меры по привлечению организация и учреждений к физической активности путем разработки комплекса программ для их работников. Определена сущность региональной системы развития бизнеса, описаны принципы ее функционирования и условия реализации.

Ключевые слова: региональная система развития бизнеса, управления, физическая активность, производительность труда, стейкхолдеры.

Постановка проблеми у загальному вигляді і її зв'язок 3 важливими науковими та практичними завданнями. Важливою рушійною силою економіки розвинених країн $\epsilon$ формування регіональних систем розвитку бізнесу, які не тільки рекомендуються, але й необхідні для забезпечення соціальноекологічного та економічного розвитку регіону, забезпечення його безпеку. 3 огляду на стрімку глобалізацію та інтенсивний розвиток інформаційних і комунікаційних технологій, дедалі більше стейкхолдерів беруть участь в побудові регіональних систем розвитку бізнесу. Вони $\epsilon$ комплексом наукових, технологічних, виробничих, організаційних, фінансових, 
Економічні науки: збірник наукових праџь Луцького національного технічного університету. - Серія "Регіональна економіка". - Випуск 16 (63). - Редкол.: відп. ред. д.е.н., професор Л.Л. Ковальська - Луцьк : ІВВ Луиького НТУ, 2019. - 173 с.

комерційних, соціальних та екологічних заходів, сукупність яких приводить до впровадження нових або удосконалення існуючих продуктів, послуг та забезпечує безпеку регіону.

Залучення стейкхолдерів до регіональних систем розвитку бізнесу сприяє своєчасному забезпеченню ресурсами і росту конкурентоспроможності регіону. Залучення зовнішніх та внутрішніх стейкхолдерів у бізнес буде сприяти збільшенню матеріальних ресурсів, створення сприятливих умов для ведення бізнесу, оперативності прийняття та реалізації рішень. Тому в процесі управління перетворенням та розвитком необхідно враховувати думки та інтереси всіх зацікавлених сторін. Управляти розвитком регіональних виробничих систем бізнесу можна через підтримання активності та працездатності стейкхолдерів, яке досягається при підвищеній фізичній активності останніх.

Зважаючи на це варто приділити увагу побудові регіональних систем розвитку бізнесу через управління фізичною активністю стейкхолдерів. Завдяки цьому покращиться соціальний та економічний розвиток регіону, підвищаться його рейтингові позиції серед регіонів.

Аналіз останніх досліджень, у яких започатковано вирішення проблеми. Вперше ідею врахування зацікавлених сторін та їх інтересів в рамках функціонування тих чи інших сфер або об'єктів запропонував Е. Фріман. Згідно його авторської трактовки стейкхолдери - це будь-які індивіди, групи або організації, які здійснюють суттєвий вплив на схвалювані фірмою рішення та/або які опиняються під впливом цих рішень [9, с. 25]. Використання стейкхолдерського підходу в управлінні функціонуванням та розвитком регіону та його територіальних одиниць субрегіонального рівня, або субрегіону, набуло своєї популярності відносно нещодавно. Так, в науковій літературі з'явились публікації, присвячені загальним засадам застосування стейкхолдерського підходу у стратегічному управлінні розвитком територій [6; 8]. У працях [7] розроблено моделі для аналізу взаємодії стейкхолдерів інноваційного проекту; у праці [5] побудовано регіональну виробничу систему 
Економічні науки: збірник наукових праиь Луиького національного технічного університету. - Серія "Регіональна економіка". - Випуск 16 (63). - Редкол.: відп. ред. д.е.н., професор Л.Л. Ковальська - Луцьк : ІВВ Луцького НТУ, 2019. -173 с.

на японській філософії кайдзен, а в [3; 4] відзначчений вплив фізичної активності на бізнес, запропоновано заходи зменшення втомллюваності та підвищення працездатності.

Проте в їхніх роботах проводилося дослідження лише окремих аспектів, які стосуються регіональних систем розвитку бізнесу через фізичну активність стейкхолдерів. Проте до сьогодні відсутній комплексний підхід до цих двох понять.

Цілі статті. Враховуючи складну природу регіональних систем розвитку бізнесу, поліаспектність його змістовного наповнення, а також відсутність виважених підходів до поєднання фізичної активності та ефективності функціонування регіональних систем бізнесу, виникає необхідність дослідження цих систем через підвищення фізичної активності стейкхолдерів. Це забезпечить зростання продуктивності праці та соціально-екологічний розвиток регіону. Поза дослідженнями вчених залишається багато суперечливих і водночас актуальних питань щодо цієї проблеми. Тому вважаємо необхідним сконцентрувати увагу і обгрунтувати авторську позицію щодо цього питання.

Виклад основного матеріалу дослідження 3 обгрунтуванням отриманих наукових результатів. Стейкхолдер (зацікавлена сторона) - фізична особа або організація, що має права, частку, вимоги або інтереси щодо системи або їі властивостей, що задовольняють їх потребам та очікуванням [1]. Стейкхолдери забезпечують можливості для системи (внесок) і є джерелом вимог для системи (стимул). Внесок - це матеріальні ресурси або послуги, внесені зацікавленими сторонами в проект із метою участі та отримання прибутку. Стимули - це блага, які можуть задовольнити потреби людини при виконанні ним певних дій [2]. Зацікавлена сторона може впливати або ж бути під впливом регіональної системи. Зацікавлені сторони можуть бути учасником регіональних систем розвитку бізнесу, або мають інтереси, на які може вплинути розвиток регіону. Оскільки стейкхолдерів розглядають як фізичних, так і юридичних осіб, то підходи до підвищення фізичної активності будуть різними. Розглянемо два 
Економічні науки: збірник наукових праџь Луцького національного технічного університету. - Серія "Регіональна економіка". - Випуск 16 (63). - Редкол.: відп. ред. д.е.н., професор Л.Л. Ковальська - Луцьк : ІВВ Луцького НТУ, 2019. - 173 с.

підходи:

1) заходи із впливу на фізичних осіб через залучення їх до спортивних змагань, створення різного роду розіграшів із виграшем - відвідуванням закладів, що займаються фізичною активністю населення регіону за нижчими цінами, створення промоційних роликів про здоровий спосіб життя;

2) заходи із залучення організація та установ до фізичної активності через розробку комплексу програм для їх працівників, популяризація здорового способу життя, розробка систем подолання втоми під час праці, підвищення продуктивності праці на підприємствах, створення тренінгів, симпозіумів та конференцій, які б пропагували фізичну активність як інструмент зменшення навантаження на економіку регіону.

У профілактиці стомлення і перевтоми працівника значна роль належить організації раціонального режиму праці i відпочинку. Фізіологи обгрунтували такі умови підвищення працездатності, що сприяють ефективному попередженню стомлення: 1) у будь-яку роботу потрібно входити поступово; 2) умовою успішної працездатності є розміреність і ритмічність; 3) послідовність і плановість виконання завдань; 4) недбалість і квапливість у праці $є$ неприпустимою; 5) фізіологічно обгрунтоване чергування праці і відпочинку, а також зміна форм діяльності (найефективнішим $є$ відпочинок, пов'язаний 3 активним діяльним станом); 6) сприятливе відношення суспільства до праці (мотивація праці і соціальні умови) $[3$, c. 35].

Низька фізична активність населення як розвинених, так і країн світу обходиться світовій економіці приблизно в 67,5 млрд дол. на рік, свідчать дані дослідження. Вперше вчені зробили спробу оцінити економічні наслідки малорухомості. У дослідженні стверджується, що всі суми є результатом надто консервативного аналізу, і фактичний збиток може бути вищим. Вчені оцінювали витрати на підтримку здоров'я, підірваного низькою фізичною активністю, збиток від зниження продуктивності праці і тривалість життя 3 поправкою на роки 
Економічні науки: збірник наукових праџь Луцького національного технічного університету. - Серія "Регіональна економіка". - Випуск 16 (63). - Редкол.: відп. ред. д.е.н., професор Л.Л. Ковальська - Луцьк : ІВВ Луцького НТУ, 2019. -173 с.

можливої інвалідності. Близько 58,8 млрд дол. представляють витрати, пов'язані з охороною здоров'я, ще 13,7 млрд дол. втрати продуктивності праці. Більше $40 \%$ загальної суми (27,8 млрд дол.) припадає на США. У країнах, що розвиваються, економічний збиток значно менший, ніж у розвинених, однак жителі держав 3 низьким рівнем доходів на душу населення частіше страждають від різних захворювань, пов'язаних 3 малорухливим способом життя. В дослідженні були розглянуті дані з 142 країн, в яких проживають 93,2\% світового населення [4].

Висновки. Отже, регіональна система розвитку бізнесу це сукупність виробничих, фінансових, комерційних, соціальних, екологічних, спортивно-оздоровчих заходів в регіоні, які підвищують конкуренту позицію регіону серед інших регіонів Україні, впливають на продуктивність праці та здоров'я населення, підвищують рівень задоволеності праці, особистого та суспільного життя. Побудова регіональна система розвитку бізнесу за принципами прозорості, відкритості, ефективності, екологічності, взаємопідтримки сприятиму підвищенню добробуту та закладенню основ сталого соціоеколого-економічного розвитку територій. Оскільки кожна особа, яка бере участь у регіональній системі розвитку бізнесу $є$ стейкхолдером, то варто більше уваги приділяти заходам із управління їхньою фізичною активністю задля досягнення соціо-еколого-економічного сталого розвитку регіону. Внеском стейкхолдерів до регіональної системи розвитку бізнесу є влад та стимули. Владом можуть бути технології, інновації, час, професійні навички, знання, кваліфікація, м'які та тверді компетенції. Стимулами виступатимуть доступ до сучасних технологій управління, можливість проведення експериментів через відкритість суспільства, підвищення кваліфікації, винагорода у покращенні рівня задоволеності працею, особистісним та суспільним життям в регіоні, безпечні умови праці, укомплектована регіональна матеріально-технологічна база, доступність до енергозберігаючих технологій, поліпшення екологічного стану, обмін досвідом із розвинутими регіонами та 
Економічні науки: збірник наукових праџь Луцького національного технічного університету. - Серія "Регіональна економіка". - Випуск 16 (63). - Редкол.: відп. ред. д.е.н., професор Л.Л. Ковальська - Луцьк : ІВВ Луцького НТУ, 2019. -173 с.

територіями. Основними перевагами управління стейкхолдерами в регіональних системах бізнесу є: пріоритети регіонального розвитку повинні бути ясними і мати спільне бачення серед його ключових впливових осіб; визначення, хто $€$ основними стейкхолдерами, і розуміння їхнього ставлення до цих систем; об'єднання людей включаючи їх знання та досвід для спільного розв' язання проблем; визначення стратегії регіону для отримання конкурентної переваги; зниження рівня ризику в регіоні та підвищення рівня безпеки.

Ефективна взаємодія допомагає перетворити потреби зацікавлених сторін в організаційні цілі та створює основу для розробки ефективної стратегії. Виявлення точки консенсусу або загальної мотивації допомагає групі стейкхолдерів перетворити інвестиції на значимий результат. Щоб регіональна система бізнесу була успішною, всі сторони повинні мати чітке розуміння процесу та цілей. Інформація має передаватися цілеспрямовано і послідовно на кожному етапі. Стейкхолдери мають розуміти бачення і ту роль, яку вони індивідуально відіграють у досягненні цілей регіону. Кожен стейкхолдер має розуміти своє значення та яку саме індивідуальну роль вони відіграють для досягнення спільної мети. Багато заходів, які запропоновано через підвищення фізичної активності стейкхолдерів не можуть бути реалізовані через низьку поінформованість та відсутність взаємодії між ними. Взаємодія зі стейкхолдерами з самого початку допомагає залучити їх $\mathrm{y}$ регіональну систему бізнесу та переконати в його успішному завершенні. Стейкхолдерам, які не розуміють стратегію розвитку громади, важко залишатися залученими і рухатися далі в потрібному напрямі.

1. ДСТУ ISO/IEC/IEEE 15288:2016. Інженерія систем і програмного забезпечення. Процеси життєвого циклу систем. Переклад з англ. Чинний від 01.01.2018. Київ : ДП «УкрНДНЦ»,2018. 90 с.

2. Ілляшенко К.В. Менеджмент персоналу. Конспект лекцій для студ. спец. 7.050104 та 8.050104 «Фінанси» усіх форм навчання та слухачів ЦПО. Суми : СумДУ, 2010. 79 с. 
Економічні науки: збірник наукових праџь Луцького національного технічного університету. - Серія "Регіональна економіка". - Випуск 16 (63). - Редкол.: відп. ред. д.е.н., професор Л.Л. Ковальська - Луцьк : ІВВ Луцького НТУ, 2019. -173 с.

3. Марчишина Є.I., Мельник В.В., Гречишин О.М. Важкість праці як психофізіологічний небезпечний та шкідливий чинник виробництва. Охорона праці. 2015. №3-4 (148-149) березень-квітень. С. 31-35.

4. Низька фізична активність населення обходиться світовій економіці приблизно в \$67,5 млрд на рік - 3MI. URL: https://news.finance.ua/ua/news//381245/nyzka-fizychna-aktyvnist-naselennya-obhodytsya-svitovij-ekonomitsipryblyzno-v-67-5-mlrd-na-rik-zmi (дата звернення 31.07.2016).

5. Полінкевич О.М. Побудова регіональних виробничих систем на японській філософії кайдзен. Економічні науки. Серія «Рехіональн економіка»: зб. наук. праць. Луиььк. нац. техн. ун-ту. 2017. Вип. 14 (55). С. 255-262

6. Тажитдинов И.А. Применение стейкхолдерского подхода в стратегическом управлении развитием территорий. Экономика региона. 2013. № 2. C. 17-27.

7. Трифонова А.І., Доценко Н.В. Розробка моделі для аналізу взаємодії стейкхолдерів інноваційного проекту. Вчені записки ТНУ імені B.I. Вернадського. Серія: технічні науки. 2019. № 2. Ч. 1. Том 30 (69). C. 220-225.

8. Тяжкороб I. В. Стратегічне партнерство у соціально-економічному розвитку регіональних систем. Прометей : регіон, зб. наук, працьь з економіки. 2011. Вип. 3 (36). С. 120-122.

9. Freeman E. Strategic Management. A Stakeholder Approach. Boston : Pitman, 1984. 231 p. 